Check for updates

Cite this: RSC Adv., 2018, 8, 38108

Received 19th July 2018

Accepted 5th November 2018

DOI: 10.1039/c8ra06127k

rsc.li/rsc-advances

\section{Implications for biomass/coal combustion emissions and secondary formation of carbonaceous aerosols in North China $\uparrow$}

\author{
Shuang Wang, ${ }^{a}$ Chandra Mouli Pavuluri, (D) *a Lujie Ren, $^{a}$ Pingqing Fu, (D) ${ }^{a}$ \\ Yan-Lin Zhang ${ }^{10}{ }^{b}$ and Cong-Qiang Liu $^{a}$
}

To understand the origins, secondary formation and seasonality of carbonaceous aerosols in North China, we collected $\mathrm{PM}_{2.5}$ samples on day- and night-time bases in summer and winter 2016 from a typical metropolis, Tianjin, and studied their carbonaceous components and stable carbon isotope ratios of total carbon $\left(\delta^{13} \mathrm{C}_{\mathrm{TC}}\right) . \mathrm{PM}_{2.5}$ ranged from $21.2 \mu \mathrm{g} \mathrm{m}^{-3}$ to $74.8 \mu \mathrm{g} \mathrm{m}^{-3}$ in summer and $25.3-$ $816 \mu \mathrm{g} \mathrm{m}^{-3}$ in winter. On average, organic carbon (OC) elemental carbon (EC) and water-soluble OC were found to be higher (3-5 times) in winter than that in summer. Secondary organic carbon that estimated by EC-tracer method was enhanced by a factor of 7 in winter compared to that in summer. $\delta^{13} \mathrm{C}_{\mathrm{TC}}$ showed a small enrichment of ${ }^{13} \mathrm{C}$ (average $-25.41 \pm 0.34 \%$ ) in summer compared to that $(-24.42 \pm 0.44 \%$ in winter. Linear relations and mass ratios of selected carbonaceous components and $\delta^{13} \mathrm{C}_{\mathrm{TC}}$ imply that the carbonaceous aerosols in Tianjin were mainly derived from biomass burning emissions and photochemical processing in summer. In winter, coal combustion emissions and in situ secondary formation of organics, including water-insoluble OC (WIOC), were dominant. This study warrants a need to understand the formation mechanisms of WIOC in the urban atmosphere and thus to reconcile the atmospheric models.

\section{Introduction}

Carbonaceous aerosols are composed of elemental carbon (EC) and many organic compounds that are collectively considered as organic carbon (OC) or organic matter. ${ }^{1}$ They account for a major fraction (5-9\% EC and $20-50 \%$ OM) of fine $\left(\mathrm{PM}_{2.5}\right)$ particle mass in mid-latitudes including in China. ${ }^{2,3}$ EC is derived from incomplete combustion of fossil fuel and biomass burning. OC can be directly emitted into the atmosphere (primary) from anthropogenic and natural (soil dust and biota) sources and can also be formed by oxidation of reactive organic gases of both the origins and subsequent gasto-particle conversion in the atmosphere (secondary)., According to solubility in water, $\mathrm{OC}$ is further classified into two groups: water-soluble OC (WSOC) and water-insoluble OC (WIOC). It is generally believed that WSOC is mainly derived by secondary formation ${ }^{6}$ but biomass burning also contributes significantly. ${ }^{7}$ WIOC is thought to be mainly from primary origins with a substantial contribution from fossil fuel

${ }^{a}$ Institute of Surface-Earth System Science, Tianjin University, Tianjin 300072, China. E-mail: cmpavuluri@tju.edu.cn; Tel: +862287370995

${ }^{b}$ Yale-NUIST Center on Atmospheric Environment, Nanjing University of Information Science and Technology, Nanjing 10044, China

$\dagger$ Electronic supplementary information (ESI) available. See DOI: 10.1039/c8ra06127k combustion and marine emissions. ${ }^{8}$ However, recent studies indicate that the contribution of WIOC from biomass burning and secondary formation are also significant. ${ }^{9}$

Carbonaceous aerosols have received great attention in recent times due to their adverse effects on environment, climate, agriculture yields, public health and visibility. ${ }^{10-17}$ They also play an important role in chemistry of the atmosphere. ${ }^{18} \mathrm{EC}$ is a strong absorber of sunlight and causes positive radiative forcing (warming) at the top of the atmosphere and the negative radiative forcing (cooling) at the Earth's surface, whereas OC is highly reflective to sunlight and cause cooling effect. ${ }^{19}$ WSOC can alter the hygroscopic properties of atmospheric aerosols and thus enhance the capability of particles to act as cloud condensation nuclei $(\mathrm{CCN})^{20,21}$ that should result in the indirect radiative forcing..$^{22,23}$

In recent times, high aerosol loadings contributed from both primary emissions and secondary formation are commonly observed in the East Asian atmosphere ${ }^{24,25}$ due to enhanced development of urbanization and industrialization, particularly in China, and the studies on carbonaceous aerosols have received a great attention in China. ${ }^{26-30}$ However, the origins and secondary formation processes of carbonaceous aerosols are not yet fully understood. It has been identified that North China is suffering from serious air pollution with extremely high aerosol loading and poor visibility in recent years. ${ }^{31,32}$ Tianjin is the most rapidly developing region in 
North China located to the southeast of Beijing and hence it is considered as an ideal location in the North China for aerosol measurements. Studies on aerosol measurements in Tianjin are scarce and focused only on mass concentrations of $\mathrm{PM}_{2.5}$, EC and OC and/or inorganic ions. ${ }^{31-34}$ Hence it is necessary to conduct comprehensive investigations of $\mathrm{PM}_{2.5}$ in Tianjin for various chemical and isotopic compositions to better understand the origins and secondary formation of aerosols in North China.

For this reason, we conducted fine aerosol $\left(\mathrm{PM}_{2.5}\right)$ sampling campaign in urban Tianjin in winter and summer 2016. Here we report the concentrations of carbonaceous components (OC, EC, WSOC, WIOC and secondary OC (SOC)) and stable carbon isotope ratios of total carbon $\left(\delta^{13} \mathrm{C}_{\mathrm{TC}}\right)$ in $\mathrm{PM}_{2.5}$ and their seasonal variations. $\delta^{13} \mathrm{C}_{\mathrm{TC}}$ is a very useful proxy to investigate the origins and photochemical processing (aging) of aerosols. ${ }^{35-40}$ Based on the results obtained from this study together with the backward air mass trajectories, we discuss the sources of carbonaceous aerosols including the influence of long-range transport of the air masses and secondary formation in North China. This paper also provides a baseline data of air quality in Tianjin, which would help to develop strategies to mitigate $\mathrm{PM}_{2.5}$ pollution in North China.

\section{Experimental section}

Tianjin is a typical metropolis and the largest coastal city in North China, located at $39^{\circ} \mathrm{N}$ and $117^{\circ} \mathrm{E}$ on the lower reaches of Haihe River and adjacent to the Bohai Sea (see Fig. S1 in the ESI $\dagger$ ), with a population of approximately 13 million and covering a land area of about $12000 \mathrm{~km}^{2}$ (https:// en.wikipedia.org/wiki/Tianjin). The weather is influenced by the East Asian monsoon prevailing with cold and dry winter and hot and humid summer seasons. Coal is the main source of energy and the industrial terminal energy consumption accounts for about $66 \%$ to the total energy consumption, which is higher than that in Beijing and Shanghai. ${ }^{\mathbf{4 1}}$

Fine aerosol $\left(\mathrm{PM}_{2.5}\right)$ sampling was performed at Tianjin University Weijin Lu campus, Nankai district in central Tianjin. $\mathrm{PM}_{2.5}$ samples were collected on the roof top of a six-story building (about $20 \mathrm{~m}$ above ground level (AGL)) number 16 on day- (7:30 am to 7:00 pm local time) and night-time (7:30 pm to 7:00 am) bases in summer (July 6-19; $n=27) 2016$ using a high volume sampler (Tisch TE-PM ${ }_{2.5}$ HVP-BL) and pre-combusted (450 $\left.{ }^{\circ} \mathrm{C}, 4 \mathrm{~h}\right)$ quartz fiber filters (Pallflex 2500QAT-UP). Because the regional weather conditions remain relatively stable and no haze events occur in summer in Tianjin region, we consider that the midsummer $(\sim 2$ week) period should represent the whole summer scenario. Whereas in winter, the $\mathrm{PM}_{2.5}$ samples were collected on the rooftop ( $\left.20 \mathrm{~m} \mathrm{AGL}\right)$ of the building number 26 during November 10 to December 23, 2017 from 8:00 am to 7:30 pm for day- and 7:40 pm to 7:40 am for night-time $(n=85)$. One blank filter sample was also collected in each season. After sampling, the filter samples were wrapped in aluminum foil and then sealed in zip-lock plastic bags and stored in freezer at $-20{ }^{\circ} \mathrm{C}$ until analysis.
EC and OC were measured using an OC/EC analyzer (Sunset Laboratory Inc., USA) following IMPROVE thermal-optical transmittance protocol as described elsewhere ${ }^{9}$ and assuming the carbonate carbon to be negligible. Briefly, a filter disc ( $1.8 \mathrm{~cm}$ in diameter) was placed in the thermal desorption chamber and then stepwise heating was applied in a He flow first and then after the initial ramp, the He gas was switched to $\mathrm{He} / \mathrm{O}_{2}$ mixture. The evolved $\mathrm{CO}_{2}$ at different steps was measured by a non-dispersive infrared (NDIR) detector and the transmittance of light through the filter was used for OC correction. The analytical errors in duplicate analyses were within $2.26 \%$ for OC and $5.27 \%$ for EC.

An aliquot $\left(4.52 \mathrm{~cm}^{2}\right)$ of each filter sample was extracted with organic free Milli-Q water under ultrasonication for $20 \mathrm{~min}$. The water extracts were then passed through a syringe filter (Millex$\mathrm{GV}, 0.22 \mu \mathrm{m}$, Millipore) and then measured for water-soluble organic carbon (WSOC) using a TOC analyzer (Shimadzu 5000A). The analytical error in duplicate analysis was within $5.52 \%$.

Concentrations of EC, OC and WSOC were corrected for field blanks. The sum of OC and EC was considered as TC. The difference between OC and WSOC was considered as WIOC.

Due to lack of analytical method to separate SOC from primary OC (POC), an indirect approach was used to estimate the SOC by EC-tracer method, since EC and POC are emitted only from primary (combustion) sources (Turpin and Huntziker, 1995), assuming the POC contribution from noncombustion sources was negligible. Because the OC/EC ratio is assumed to be relatively constant for a given location and local meteorology, the minimum OC/EC observed in each season can be considered separately as a representative ratio of primary emissions for that location and season, ${ }^{\mathbf{4 2}}$ although it involves some degree of uncertainty. In this study, we estimated the SOC according to the following equation: $\mathrm{SOC}=\mathrm{OC}$ $-\left[\mathrm{EC} \times(\mathrm{OC} / \mathrm{EC})_{\mathrm{min}}\right]$. The possible uncertainties were checked using the lowest $5 \%$ of OC/EC values as primary OC/EC ratio. ${ }^{43}$ The uncertainty for the average SOC was $9.14 \%$ in summer and $25.9 \%$ in winter. These uncertainties are lower/comparable to that $( \pm 28 \%)$ reported in other study, in which the primary OC/ EC was estimated from linear regression of the datasets of the primary-dominated OC and EC. ${ }^{\mathbf{8}}$ Therefore, the SOC estimated using $(\mathrm{OC} / \mathrm{EC})_{\min }$ as the primary $\mathrm{OC} / \mathrm{EC}$ in this study is reasonable.

$\delta^{13} \mathrm{C}_{\mathrm{TC}}$ is determined using elemental analyzer coupled with isotope ratio mass spectrometry (EA/irMS, MAT253). A filter disc of (1.4 cm in diameter) sample was placed in a tin cup, introduced into EA and then oxidized in a combustion column packed with $\mathrm{CuO}$ at $1020{ }^{\circ} \mathrm{C}$. The derived $\mathrm{CO}_{2}$ (and $\mathrm{N}_{2}$, obtained from $\mathrm{NO}_{x}$ ) gases were transferred into EA/irMS via an interface (Conflo II) for isotope ratio measurement. The $\delta^{13} \mathrm{C}_{\mathrm{TC}}$ values relative to Pee Dee Belemnite (PDB) were calculated according to the standard equation: $\delta^{13} \mathrm{C}=\left(R_{\text {sample }} /\right.$ $\left.R_{\text {standard }}-1\right)$ where $R$ is the ratio of ${ }^{13} \mathrm{C} /{ }^{12} \mathrm{C}$. The analytical error based on duplicate analyses in the $\delta^{13} \mathrm{C}_{\mathrm{TC}}$ was within $0.1 \%$. $\mathrm{PM}_{2.5}$ samples were not decarbonated prior to the measurements assuming that Tianjin aerosols may contain negligible amount of $\mathrm{CaCO}_{3}$ and its impact on the $\delta^{13} \mathrm{C}_{\mathrm{TC}}$. 


\section{Results and discussion}

\section{Concentrations and temporal variations of carbonaceous components}

Summary of Tianjin aerosol $\left(\mathrm{PM}_{2.5}\right)$ mass and concentrations of carbonaceous components in the $\mathrm{PM}_{2.5}$ in day- and night-time in summer and winter are presented in Table 1. The mass concentration of $\mathrm{PM}_{2.5}$ varied from $21.2 \mu \mathrm{g} \mathrm{m}^{-3}$ to $74.8 \mu \mathrm{g} \mathrm{m}^{-3}$ with an average of $40.1 \pm 12.5 \mu \mathrm{g} \mathrm{m}^{-3}(n=27)$ in summer and 25.3-816 $\mu \mathrm{g} \mathrm{m}^{-3}$ (ave. $207 \pm 146 \mu \mathrm{g} \mathrm{m}^{-3} ; n=85$ ) in winter. OC ranged from $3.75-6.55 \mu \mathrm{g} \mathrm{m}^{-3}$ with an average $4.90 \pm 0.91 \mu \mathrm{g}$ $\mathrm{m}^{-3}$ in summer and 5.33-79.8 $\mu \mathrm{g} \mathrm{m}^{-3}$ (ave. $23.6 \pm 13.4 \mu \mathrm{g} \mathrm{m}^{-3}$ ) in winter. On average, both $\mathrm{PM}_{2.5}$ and OC were found to be higher in winter by a factor of $\sim 5$ than that in summer. Similarly, EC (ave. $2.55 \mu \mathrm{g} \mathrm{m}^{-3}$ ) was four times higher in winter than that (ave. $0.66 \mu \mathrm{g} \mathrm{m} \mathrm{m}^{-3}$ ) in summer. The enhancement in OC loading in winter than that of EC suggests that secondary formation of the OC should be significant and/or its emission from coal combustion/biomass burning might be higher in winter. Averages of WSOC were $3.08 \pm 0.81$ and $9.58 \pm 5.92 \mu \mathrm{g}$ $\mathrm{m}^{-3}$ in summer and winter, respectively. It is worthy to note that the average concentration of WIOC was found to be highly enhanced in winter compared to that of WSOC, despite the fact that the average SOC in winter $\left(13.9 \mu \mathrm{g} \mathrm{m}^{-3}\right)$ was nearly 7 times higher than that in summer $\left(2.03 \mu \mathrm{g} \mathrm{m}^{-3}\right)$.

However, as shown in Fig. 1, all carbonaceous components, except SOC, and $\mathrm{PM}_{2.5}$ as well showed no diurnal variation in both summer and winter. The SOC was found to be higher in daytime than that in nighttime in summer. The intensive sunlight and high temperature prevailed at local region should have promoted the enhanced formation of SOC in summer. Interestingly, the high abundance of WSOC than that of SOC in summer implies that the WSOC should have been derived from local primary emissions (e.g., biomass burning) as well. Whereas the high abundance of SOC in winter than that of WSOC in winter indicate that part of the SOC is water-insoluble in winter, although we do not preclude the uncertainties involved in the WSOC measurement and SOC estimation. In addition, WIOC was a major fraction of OC and accounted for $61 \%$ of the OC in winter. In fact, WIOC, SOC and WSOC showed a similar temporal trend in winter, which suggest that they should have been originated from same/similar sources and their formation processes might also be similar.

\section{Comparison of OC and EC with literature}

Concentrations of OC and EC, and OC/EC ratios observed in Tianjin $\mathrm{PM}_{2.5}$ and those reported from other metropolitan areas over mainland China and other locale over the world are presented in Table 2 . The summertime OC and EC observed during our campaign in Tianjin were lower than those reported from Beijing, Shanghai, Xi'an, Chongqing, Taiyuan, Nanjing and Guangzhou, China as well as those reported in Tianjin in 2003 and 2010 (Table 2). However, the OC observed in winter was higher than that reported from Tianjin in 2010, Shanghai, Nanjing and Chongqing but much lower than that at Xi'an and comparable with that at Guangzhou (Table 2). In contrast, the EC observed in Tianjin is lower than that reported from most of Chinese cities, but comparable with that reported at Taiyuan (Table 2), indicating that the contribution of carbonaceous aerosols from coal combustion should be significant in Tianjin. In fact, coal is the major source of energy in Taiyuan and its consumption is high in winter, and the $\mathrm{PM}_{2.5}$ pollution is highest in Taiyuan over China.

Furthermore, the OC and EC levels in Tianjin $\mathrm{PM}_{2.5}$ in winter were substantially higher than those in Vancouver and Toronto, Canada and New York (Table 2). Compared with the previous studies in Tianjin, the level of EC is greatly decreased but the OC loading remained at higher levels, particularly in winter. In addition, $\mathrm{PM}_{2.5}$ was maximized in winter. Such high loading of $\mathrm{PM}_{2.5}$ and $\mathrm{OC}$ and their comparisons with the literature suggest that the aerosol pollution is significantly high in Tianjin and the emissions from coal combustion should be a major source, particularly in winter due to its high consumption for space heating.

\section{Linear relations and mass ratios of selected components: implications for sources}

It is well known that EC is generated from only primary sources such as fossil fuel combustion and biomass burning. Further the fraction of EC in the particles emitted from those sources

Table 1 Summary of carbonaceous components $\left(\mu \mathrm{g} \mathrm{m}^{-3}\right)$ in $\mathrm{PM}_{2.5}$ samples collected on day- and night-time bases in summer (July 6-19) and winter (November 10 to December 23) 2016 together with mass $\left(\mu \mathrm{g} \mathrm{m}^{-3}\right.$ ) of the $\mathrm{PM}_{2.5}$ in Tianjin, North China ${ }^{a}$

\begin{tabular}{|c|c|c|c|c|c|c|c|c|}
\hline & \multicolumn{4}{|l|}{ Summer } & \multicolumn{4}{|l|}{ Winter } \\
\hline EC & $0.35-0.96$ & $0.59 \pm 0.19$ & $0.48-1.21$ & $0.74 \pm 0.26$ & $0.40-7.20$ & $2.35 \pm 1.57$ & $0.44-6.37$ & $2.74 \pm 1.45$ \\
\hline OC & $3.75-6.55$ & $5.25 \pm 0.96$ & $3.50-6.06$ & $4.62 \pm 0.80$ & $5.96-79.8$ & $23.4 \pm 15.7$ & $5.33-47.9$ & $24.0 \pm 11.0$ \\
\hline SOC & $1.62-3.91$ & $2.61 \pm 0.7$ & $0.00-2.69$ & $1.40 \pm 0.78$ & $1.44-53.4$ & $14.4 \pm 10.7$ & $0.04-31.5$ & $13.5 \pm 7.93$ \\
\hline $\mathrm{PM}_{2.5}$ & $21.2-55.5$ & $37.3 \pm 8.84$ & $24.6-74.8$ & $43.0 \pm 15.4$ & $32.3-695$ & $208 \pm 150$ & $25.3-816$ & $206 \pm 143$ \\
\hline
\end{tabular}

${ }^{a}$ Ave., average; SD, standard deviation. 


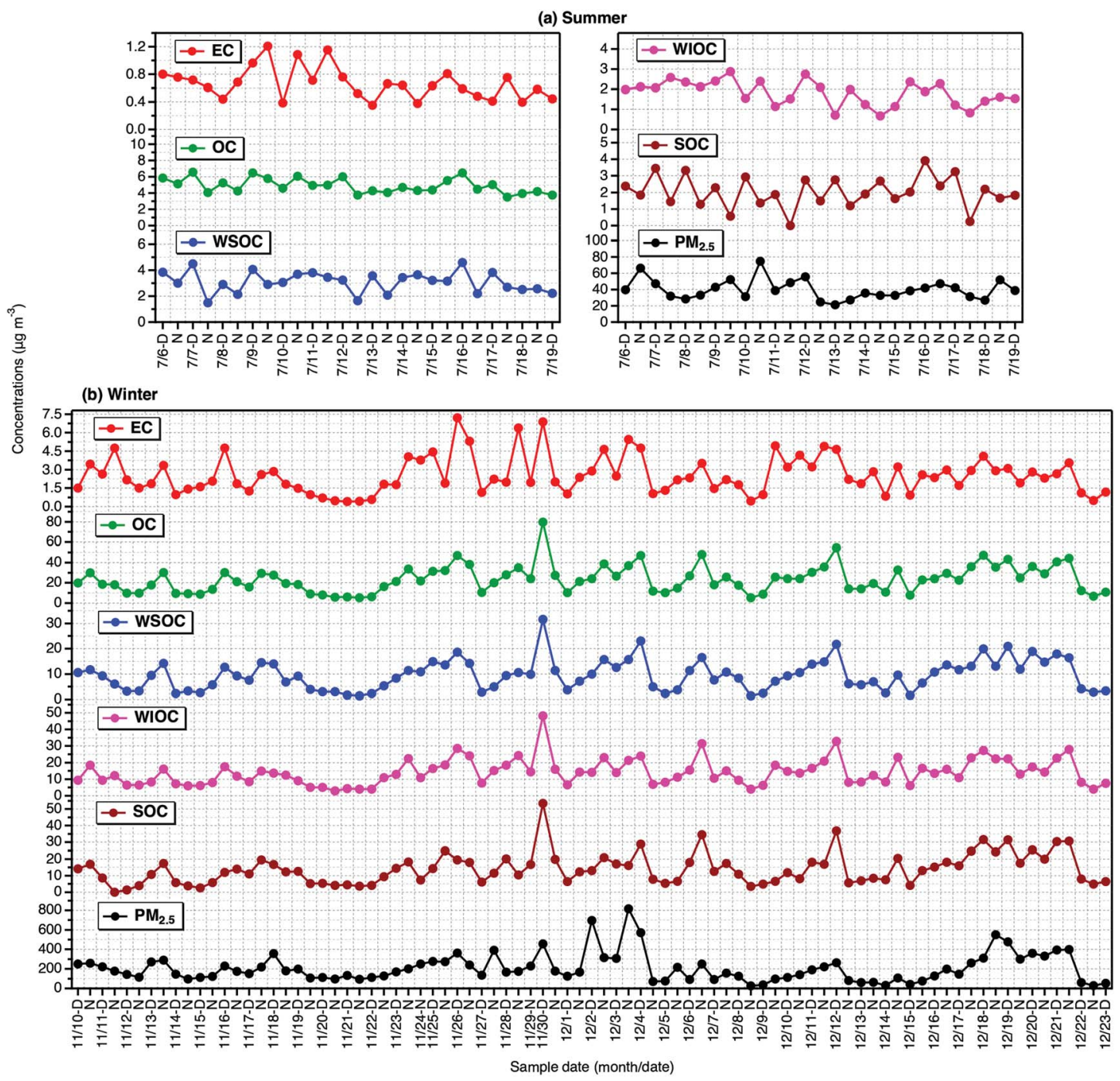

Fig. 1 Temporal variations in carbonaceous components in $\mathrm{PM}_{2.5}$ and mass of the $\mathrm{PM}_{2.5}$ collected on day- and night-time bases in (a) summer and (b) winter 2016 in Tianjin, North China.

depend on fuel type and burning conditions. ${ }^{44}$ Hence, the scatter plots between EC and OC and their mass ratios could provide insights on the origins of $\mathrm{OA}$ and the importance of secondary formation and processing in the atmosphere. As shown in Fig. 2a and b, OC showed a strong correlation with EC in Tianjin $\mathrm{PM}_{2.5}$ in winter whereas a weak correlation in summer. Such linearity implies that both EC and OC should have mainly been derived from fossil fuel combustion and/or biomass burning in winter. In summer, the other sources e.g., biogenic emission of volatile organic compounds (BVOCs) and subsequent secondary formation should have also played an important role. The higher slope value in winter than that in summer (Fig. 2a and b) indicate that the contribution of OC from primary sources must be higher in winter than that in summer.

Average mass ratios with standard deviation of selected components in day- and night-time Tianjin $\mathrm{PM}_{2.5}$ during summer and winter are depicted in Fig. 3. The OC/EC ratios varied from 4.32 to 12.2 with an average of $8.02 \pm 2.41$ in summer and 3.83-17.0 (ave. $9.94 \pm 2.78$ ) in winter. These ratios were highly comparable to those $(2.5-10.5)$ reported in the particles emitted from residential coal combustion ${ }^{45}$ and biomass burning (8.1-12.7). ${ }^{46,47}$ On the contrary, only the lower ends of OC/EC in Tianjin $\mathrm{PM}_{2.5}$ were comparable to those in diesel- and gasoline-powered vehicular exhaust (1.0-4.2). ${ }^{48,49}$ They were lower than those reported for the particles emitted from wood combustion $(16.8-40.0)^{50}$ and cooking (32.9-81.6). ${ }^{51}$ Such comparisons of OC/EC ratios with source signatures imply that Tianjin aerosols were mainly derived from coal combustion and biomass burning while vehicular exhaust might have also played an important role.

Generally, the OC/EC ratios exceeding 2.0 have been considered as an indicator to show the presence of secondary OA. ${ }^{52,53}$ In Tianjin $\mathrm{PM}_{2.5}$, it was always exceeded 2.0 in summer and winter, suggesting that secondary formation and/or transformations of OA was significant in both the seasons. On the other hand, OC/EC was higher in daytime than that in nighttime in both the seasons, although the variation was insignificant in winter (Fig. 3), which indicate that in situ photochemical formation of OA was significant in daytime. The elevated OC/EC 
Table 2 Concentrations of $\mathrm{EC}$ and $\mathrm{OC}\left(\mu \mathrm{g} \mathrm{m}^{-3}\right)$ and mass ratios of $\mathrm{OC}$ to $\mathrm{EC}$ in Tianjin $\mathrm{PM}_{2.5}$ and those in atmospheric aerosols from different locale in China, Canada and New York

\begin{tabular}{|c|c|c|c|c|c|}
\hline Tianjin & Summer 2016 & $4.90 \pm 0.91$ & $0.66 \pm 0.19$ & $8.02 \pm 2.15$ & This study \\
\hline Tianjin & Winter 2016 & $23.6 \pm 14.0$ & $2.55 \pm 1.50$ & $9.93 \pm 2.78$ & This study \\
\hline Tianjin & Summer 2003 & $16.5 \pm 4.1$ & $3.70 \pm 1.50$ & 4.90 & Cao et al. $(2007)^{3}$ \\
\hline Tianjin & Sep. 2009 to Feb. 2010 & $14.5 \pm 11.2$ & $4.30 \pm 2.90$ & 3.70 & Li et al. $(2012)^{31}$ \\
\hline Shanghai & Oct. 2005 to Aug. 2006 & $14.7 \pm 10.1$ & $2.80 \pm 1.30$ & 5.00 & Feng et al. $(2009)^{27}$ \\
\hline Beijing & Summer 2009 & $11.1 \pm 1.80$ & $4.20 \pm 1.20$ & 2.50 & Zhang et al. $(2013)^{30}$ \\
\hline Beijing & Winter 2010 & $24.9 \pm 15.6$ & $7.50 \pm 7.40$ & 2.70 & Zhang et al. $(2013)^{30}$ \\
\hline Nanjing & Feb. to Sep. 2001 & $13.2 \pm 3.40$ & $3.70 \pm 0.50$ & 3.60 & Yang et al. $(2005)^{56}$ \\
\hline Taiyuan & Dec. 2005 to Feb. 2006 & 28.9 & $2.12 \pm 0.51$ & 3.70 & Meng et al. $(2007)^{26}$ \\
\hline Chongqing & Summer 2013 & $7.49 \pm 2.37$ & $4.32 \pm 1.86$ & 3.55 & Huang et al. $(2018)^{28}$ \\
\hline Chongqing & Winter 2013 & $21.1 \pm 9.22$ & $3.80 \pm 1.40$ & 4.09 & Huang et al. $(2018)^{28}$ \\
\hline New York & Winter 2004 & 1.62 & 0.85 & ND & Venkatachari et al. $(2006)^{17}$ \\
\hline
\end{tabular}

in winter can be attributed to enhanced consumption of coal for heating and stagnant conditions in winter.

The mass fraction of WSOC in OC that can be regarded as an indicator of photochemical processing (aging) of aerosols in the atmosphere ${ }^{54}$ was accounted for $20 \%$ to $80 \%$ in Tianjin $\mathrm{PM}_{2.5}$. The WSOC/OC (0.63) was found to be higher in summer than that in winter $(0.39)$. The range $(0.37-0.84)$ and average (0.63) of WSOC/OC in Tianjin summertime aerosols were comparable to those (range $0.38-0.72$, ave. 0.66) reported at a Great Hungarian rural site situated on forest clearing area, ${ }^{55}$ at suburb of Nanjing, China $(0.40-0.51)^{56}$ and at Chennai, India (0.23-0.61), ${ }^{9}$ where biomass burning was considered as the major source of aerosols. On the other hand, they were comparable to that reported in Yellow River Delta (0.56), a regional background receptor site on the coast of Bohai Sea, where the contribution from marine biogenic emissions and secondary formation is significant. ${ }^{57}$ In fact, the air masses arrived at Tianjin in summer were originated from the Pacific
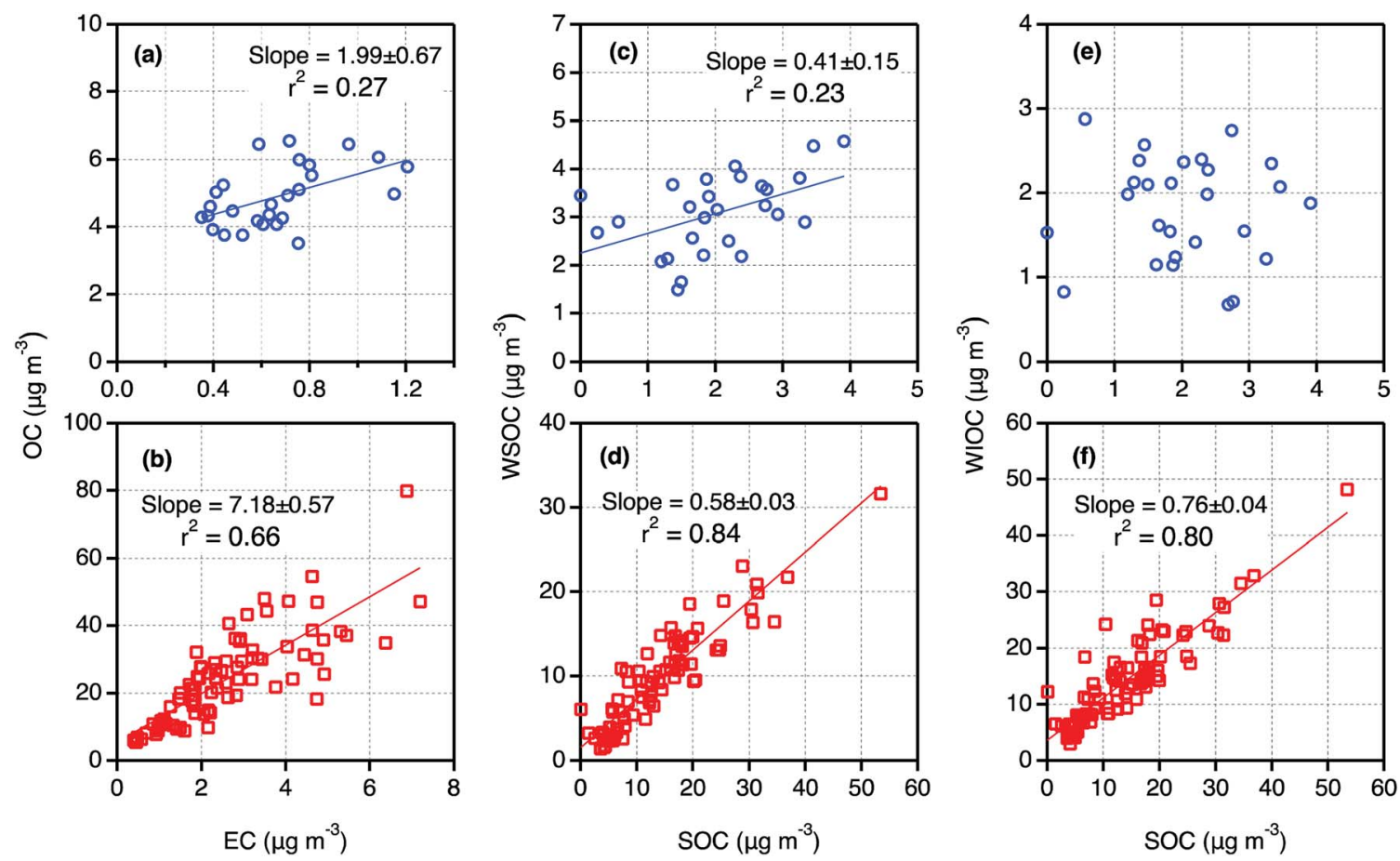

Fig. 2 Scatter plots between selected carbonaceous components in $\mathrm{PM}_{2.5}$ collected on day- and night-time bases in summer (a, c and e) and winter (b, d and f) 2016 in Tianjin, North China. 


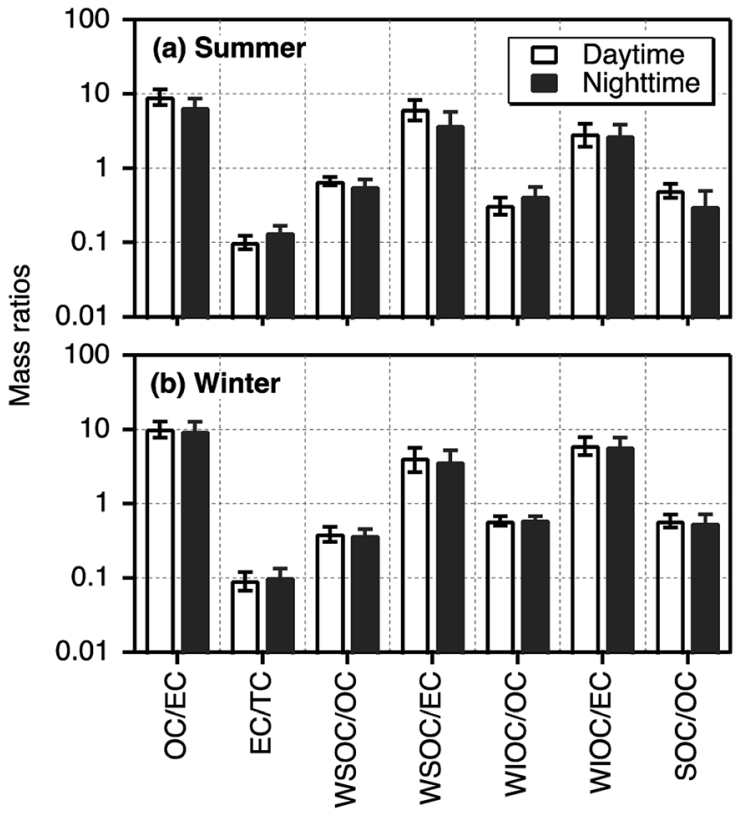

Fig. 3 Mass ratios of selected carbonaceous components in $\mathrm{PM}_{2.5}$ collected on day- and night-time bases in summer and winter 2016 in Tianjin, North China.

Ocean and passed over the Bohai Sea and coastal China (Fig. S2†).

In contrast, the range (0.20-0.53) and average (0.39) of WSOC/OC in Tianjin wintertime $\mathrm{PM}_{2.5}$ were comparable to those ( 0.19 in winter, 0.35 in summer and autumn) reported in Tokyo, where emissions from fossil fuel combustion emissions are significant. ${ }^{8}$ These comparisons suggest that the Tianjin aerosols should have been mainly originated from biomass burning and biogenic emissions and more aged in summer whereas in winter, they should have been originated from fossil fuel combustion. On the other hand, WSOC/EC was found to be much higher in daytime than nighttime in summer but not in winter (Fig. 3), which indicates that in situ photochemical formation of WSOC might also be significant in Tianjin during the summer. However, both WSOC and WIOC showed a good linear relation $\left(R^{2}=0.55\right.$ and 0.67 , respectively) with EC, which suggest that they should have been originated from anthropogenic emissions and formed by in situ secondary processes at local scale rather than from the long-range transported air masses. In fact, the consumption of coal and biomass energy is much higher in winter for space heating in Tianjin.

WIOC in the urban atmosphere is composed of aliphatic hydrocarbons, long-chain ketones, alkanols, and polycyclic aromatic hydrocarbons that are most likely generated from incomplete combustion of fossil fuels and cooking activities. ${ }^{58}$ In marine regions, the biogenic organic matter such as bacterial and viral debris as well as phytoplankton debris emitted into the atmosphere account for a major fraction of WIOC..$^{59,60}$ Interestingly, WIOC/OC did not vary between day- and nighttime, which is opposite to that of WSOC/OC in summer, whereas the average WIOC/EC showed a slightly higher value in the daytime than that in nighttime in both summer and winter (Fig. 3). Further WIOC accounted for a major fraction of OC $(61 \%)$ in winter. In addition, WIOC showed a strong correlation $\left(R^{2}=0.67\right)$ with EC in winter. Such results imply that WIOC and EC should have been originated from a common source(s) such as coal combustion and biomass burning but part of the WIOC should have been generated by in situ secondary formation.

Average WIOC/OC ratios (0.37 in summer and 0.61 in winter) in Tianjin $\mathrm{PM}_{2.5}$ were comparable to that (0.55) reported in Chennai aerosols, India, which were considered to be mainly originated from biomass burning and aged during long-range transport. ${ }^{9}$ WIOC/EC (2.88) was also comparable to that (3.6 in summer and 0.8 in winter) in Chennai aerosols ${ }^{9}$ in summer, although it (6.01) was much higher in winter. Such enhancement in the WIOC/EC in Tianjin $\mathrm{PM}_{2.5}$ is likely because OC/EC ratios highly depend on type of biofuel/biomass and burn rate ${ }^{44}$ and the contribution from coal combustion ${ }^{45}$ as well. In addition, the WIOC/EC (range, 1.10-5.31 in summer and 2.56-10.6 in winter), except the lower ends in summer, were higher than those (0.90-1.31) reported in Tokyo, where fossil fuel (excluding coal) combustion was expected as the major source. ${ }^{8}$ These comparisons further support that WIOC in Tianjin $\mathrm{PM}_{2.5}$ should have been derived from biomass burning and coal combustion as well as by secondary formation.

In consistence with the seasonality in SOC loading; high in winter and low in summer (Fig. 1), the mass ratios of SOC/OC were higher in winter $(0.58)$ than that in summer $(0.41)$ and showed no diurnal variation in winter (Fig. 3). Such seasonal pattern of both concentrations of SOC and SOC/OC are similar to that reported in Beijing. ${ }^{43}$ It is worth to note that among the measured components including WSOC, which is generally believed to be mainly generated by secondary formation in the atmosphere, ${ }^{6} \mathrm{SOC}$ is the only component that showed a clear diurnal variation at least in summer. Furthermore, we found a weak correlation between SOC and WSOC in daytime $\left(R^{2}=\right.$ 0.25 ) and no relation in nighttime during summer. It suggests that a fraction of WIOC should also have been produced by photochemical processes of gaseous organic species, and WSOC should have been significantly contributed from biomass burning in addition to the secondary formation.

In winter, both SOC and WSOC and their mass fractions in OC did not show any significant diurnal variation in winter (Fig. 3). However, the SOC showed a strong correlation with both WSOC and WIOC and their slopes were also significantly high in winter but not in summer (Fig. 2c-f). It implies that the origins and secondary formation and/or transformation processes of Tianjin aerosols in winter were different from those in summer, and also most of the WIOC was generated by secondary processes. In fact, simulations, field observation and laboratory studies reported that the secondary formation of $\mathrm{OA}$ in the Chinese atmosphere is highly enhanced in wintertime and the aqueous phase reactions have been proposed to be more prominent. ${ }^{25,61}$ Therefore, the enhanced formation of SOC, including WIOC, in Tianjin aerosols is likely, however, the formation processes of the water-insoluble organic species needs to be explored further. 
(a)

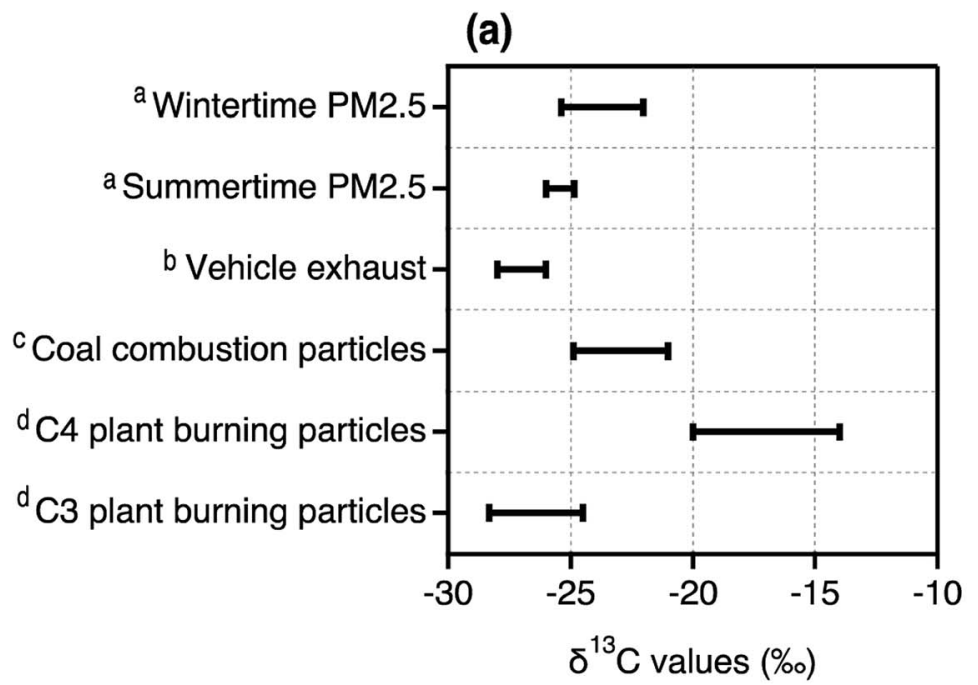

(b)

Summer

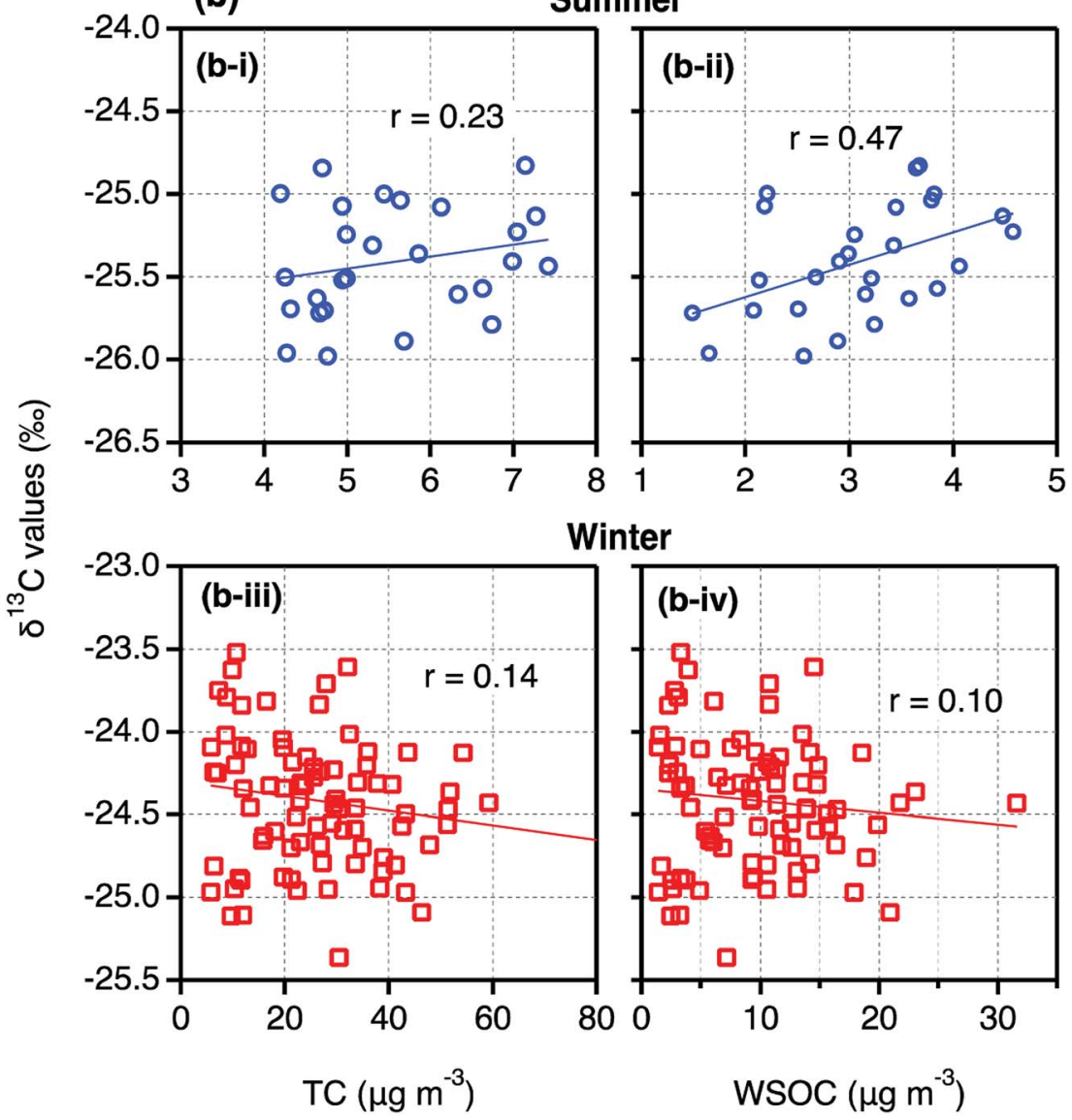

Fig. 4 (a) Ranges of $\delta^{13} \mathrm{C}_{\mathrm{TC}}$ in $\mathrm{PM}_{2.5}$ collected on day- and night-time bases in summer and winter in Tianjin, North China ( ${ }^{a}$ This study) together with those in the particles emitted from specific origins ( ${ }^{b}$ Widory et al., (2004) $)^{40}$; ${ }^{C}$ Gleason and Kyser, (1984) ${ }^{39}$; ${ }^{d}$ Martinelli et al., (2002) $\left.)^{36}\right)$. (b) Scatter plots between $\delta^{13} \mathrm{C}_{\mathrm{TC}}$ and TC and WSOC in summer and winter.

Seasonality in $\delta^{13} \mathrm{C}_{\mathrm{TC}}$ and its relations with TC and WSOC: biomass/coal combustion and secondary formation

$\delta^{13} \mathrm{C}_{\mathrm{TC}}$ in Tianjin $\mathrm{PM}_{2.5}$ ranged from $-25.98 \%$ to $-24.98 \%$ with an average of $-25.41 \%$ in summer while in winter, the $\delta^{13} \mathrm{C}_{\mathrm{TC}}$ varied between $-22 \%$ and $-35.37 \%$ (ave. $-24.42 \%$ ). As shown in Fig. $4 \mathrm{a}, \delta^{13} \mathrm{C}_{\mathrm{TC}}$ in Tianjin summertime $\mathrm{PM}_{2.5}$ were slightly higher than those reported in the particles emitted from vehicle exhaust and comparable to the higher $\delta^{13} \mathrm{C}_{\mathrm{TC}}$ values reported in the particles emitted from $\mathrm{C}_{3}$ plant biomass burning, whereas lower than those reported in the particles emitted from coal combustion. ${ }^{36,39,40}$ These comparisons imply that Tianjin $\mathrm{PM}_{2.5}$ should have been influenced by the emissions from fossil fuel 
(excluding coal) combustion and biomass burning and subjected for significant aging during long-range transport in summer. In contrast, the $\delta^{13} \mathrm{C}_{\mathrm{TC}}$ in Tianjin wintertime $\mathrm{PM}_{2.5}$ were comparable to those reported in the particles emitted from coal combustion (Fig. 4a). In addition, their lower ends were comparable to those of the higher ends reported for the particles emitted from $\mathrm{C}_{3}$ plant biomass burning (Fig. 4a). Such comparisons indicate that both coal combustion and biomass burning should be the major sources of Tianjin aerosols in winter.

As shown in Fig. $4 \mathrm{~b}, \delta^{13} \mathrm{C}_{\mathrm{TC}}$ in Tianjin $\mathrm{PM}_{2.5}$ showed a positive correlation with TC, although it is weak, in summer. Further, the linear relation of $\delta^{13} \mathrm{C}_{\mathrm{TC}}$ was higher by factor of 2 with WSOC than that with TC (Fig. 4b). On the contrary, the $\delta^{13} \mathrm{C}_{\mathrm{TC}}$ did not show a significant relation either with TC or with WSOC in winter. In fact, the linearity between them was negative, though the coefficient is very small (Fig. 4b). It is well established that formation of WSOC is increased with aging of aerosols due to photochemical transformations of OC that result in more oxygenated compounds, for example; carbonyls to carboxylic acids and to dicarboxylic acids. ${ }^{62}$ On the other hand, the ${ }^{13} \mathrm{C}$ is enriched in the compounds remained in the same phase, if some of the product species are gases, and thus the $\delta^{13} \mathrm{C}_{\mathrm{TC}}$ is increased with the aging. ${ }^{35}$ Therefore, the linear relations of $\delta^{13} \mathrm{C}_{\mathrm{TC}}$ with TC and WSOC imply that the aging of Tianjin aerosols during long-range transport is significant in summer. Whereas in winter, as noted earlier, the emissions from coal combustion and biomass burning at local scale and in situ secondary formation should be dominant rather than from the long-range transported aged air masses. The backward air mass trajectories, which were travelled at significant height AGL in summer and at lesser than $500 \mathrm{~m}$ AGL in winter (Fig. S2†), also suggest that the convection of the air masses from distant sources to Tianjin might be insignificant in winter.

\section{Summary and conclusions}

$\mathrm{PM}_{2.5}$ samples collected on day- and night-time bases in summer (July) and winter (November and December) 2016 in the Tianjin urban atmosphere, North China were studied for OC, EC, WSOC and $\delta^{13} \mathrm{C}_{\mathrm{TC}}$. WIOC was calculated from OC and WSOC concentrations and SOC was estimated by EC-tracer based approach. Concentrations of all the components were found to be higher in winter than those in summer. Further the ${ }^{13} \mathrm{C}$ was enriched in summer $\mathrm{PM}_{2.5}$ than that in the winter $\mathrm{PM}_{2.5}$. Mass ratios of WSOC/OC and WSOC/EC and $\delta^{13} \mathrm{C}_{\mathrm{TC}}$ suggest that Tianjin aerosols were derived from biomass burning and marine emissions and significantly aged during long-range atmospheric transport in summer. In contrast, the relations of OC and EC and WSOC and WIOC with SOC together with their mass ratios and $\delta^{13} \mathrm{C}_{\mathrm{TC}}$ indicate that the emissions from coal combustion and biomass burning and in situ secondary formation are dominant in winter. Finally, the results obtained from this study can be considered as a baseline data of carbonaceous aerosols in North China.

\section{Conflicts of interest}

The authors declare no conflict of interest.

\section{Acknowledgements}

This study was supported by the National Key R\&D Program of China (2017YFC0212700), the National Natural Science Foundation of China (NSFC) through Grant-in-Aid numbers: 41651001, 41775120 and 91644103, and the 985 Project of National Key Universities, Tianjin University.

\section{References}

1 D. Contini, R. Vecchi and M. Viana, Atmosphere, 2018, 9, 181. 2 M. Sillanpaa, A. Frey, R. Hillamo, A. S. Pennanen and R. O. Salonen, Atmos. Chem. Phys., 2005, 5, 2869-2879.

3 J. J. Cao, S. C. Lee, J. C. Chow, J. G. Watson, K. F. Ho, R. J. Zhang, Z. D. Jin, Z. X. Shen, G. C. Chen, Y. M. Kang, S. C. Zou, L. Z. Zhang, S. H. Qi, M. H. Dai, Y. Cheng and K. $\mathrm{Hu}, J$. Geophys. Res.: Atmos., 2007, 112, D22S11.

4 A. L. Robinson, N. M. Donahue, M. K. Shrivastava, E. A. Weitkamp, A. M. Sage, A. P. Grieshop, T. E. Lane, J. R. Pierce and S. N. Pandis, Science, 2007, 315, 1259-1262.

5 J. L. Jimenez, M. R. Canagaratna, N. M. Donahue, A. S. H. Prevot, Q. Zhang, J. H. Kroll, P. F. DeCarlo, J. D. Allan, H. Coe, N. L. Ng, A. C. Aiken, K. S. Docherty, I. M. Ulbrich, A. P. Grieshop, A. L. Robinson, J. Duplissy, J. D. Smith, K. R. Wilson, V. A. Lanz, C. Hueglin, Y. L. Sun, J. Tian, A. Laaksonen, T. Raatikainen, J. Rautiainen, P. Vaattovaara, M. Ehn, M. Kulmala, J. M. Tomlinson, D. R. Collins, M. J. Cubison, E. J. Dunlea, J. A. Huffman, T. B. Onasch, M. R. Alfarra, P. I. Williams, K. Bower, Y. Kondo, J. Schneider, F. Drewnick, S. Borrmann, S. Weimer, K. Demerjian, D. Salcedo, L. Cottrell, R. Griffin, A. Takami, T. Miyoshi, S. Hatakeyama, A. Shimono, J. Y. Sun, Y. M. Zhang, K. Dzepina, J. R. Kimmel, D. Sueper, J. T. Jayne, S. C. Herndon, A. M. Trimborn, L. R. Williams, E. C. Wood, A. M. Middlebrook, C. E. Kolb, U. Baltensperger and D. R. Worsnop, Science, 2009, 326, 1525-1529.

6 Z. Y. Du, K. B. He, Y. Cheng, F. K. Duan, Y. L. Ma, J. M. Liu, X. L. Zhang, M. Zheng and R. Weber, Atmos. Environ., 2014, 92, 514-521.

7 O. L. Mayol-Bracero, P. Guyon, B. Graham, G. Roberts, M. O. Andreae, S. Decesari, M. C. Facchini, S. Fuzzi and P. Artaxo, J. Geophys. Res., 2002, 107, D208091.

8 Y. Miyazaki, Y. Kondo, N. Takegawa, Y. Komazaki, M. Fukuda, K. Kawamura, M. Mochida, K. Okuzawa and R. J. Weber, J. Geophys. Res.: Atmos., 2006, 111, D23206.

9 C. M. Pavuluri, K. Kawamura, S. G. Aggarwal and T. Swaminathan, Atmos. Chem. Phys., 2011, 11, 8215-8230.

10 W. L. Chameides, H. Yu, S. C. Liu, M. Bergin, X. Zhou, L. Mearns, G. Wang, C. S. Kiang, R. D. Saylor, C. Luo, Y. Huang, A. Steiner and F. Giorgi, Proc. Natl. Acad. Sci. U. S. A., 1999, 96, 13626-13633. 
11 S. Menon, J. Hansen, L. Nazarenko and Y. Luo, Science, 2002, 297, 2250-2253.

12 V. Ramanathan, P. J. Crutzen, J. T. Kiehl and D. Rosenfeld, Science, 2001, 294, 2119-2124.

13 Y. Huang, R. E. Dickinson and W. L. Chameides, Proc. Natl. Acad. Sci. U. S. A., 2006, 103, 4371-4376.

14 J. L. Mauderly and J. C. Chow, Inhalation Toxicol., 2008, 20, 257-288.

15 X. H. Fan, J. R. Brook and S. A. Mabury, Atmos. Environ., 2004, 38, 5801-5810.

16 U. M. Sofowote, A. K. Rastogi, J. Debosz and P. K. Hopke, Atmos. Pollut. Res., 2014, 5, 13-23.

17 P. Venkatachari, L. M. Zhou, P. K. Hopke, J. J. Schwab, K. L. Demerjian, S. Weimer, O. Hogrefe, D. Felton and O. Rattigan, Aerosol Sci. Technol., 2006, 40, 788-795.

18 C. E. Kolb and D. R. Worsnop, Annu. Rev. Phys. Chem., 2012, 63, 471-491.

19 M. Z. Jacobson, Nature, 2001, 409, 695-697.

20 T. Novakov and J. E. Penner, Nature, 1993, 365, 823-826.

21 A. Asa-Awuku, R. H. Moore, A. Nenes, R. Bahreini, J. S. Holloway, C. A. Brock, A. M. Middlebrook, T. B. Ryerson, J. L. Jimenez, P. F. DeCarlo, A. Hecobian, R. J. Weber, R. Stickel, D. J. Tanner and L. G. Huey, J. Geophys. Res.: Atmos., 2011, 116, D11201.

22 S. Twomey, J. Atmos. Sci., 1977, 34, 1149-1152.

23 B. A. Albrecht, Science, 1989, 245, 1227-1230.

24 G. R. Carmichael, B. Adhikary, S. Kulkarni, A. D'Allura, Y. Tang, D. Streets, Q. Zhang, T. C. Bond, V. Ramanathan, A. Jamroensan and P. Marrapu, Environ. Sci. Technol., 2009, 43, 5811-5817.

25 R. J. Huang, Y. L. Zhang, C. Bozzetti, K. F. Ho, J. J. Cao, Y. M. Han, K. R. Daellenbach, J. G. Slowik, S. M. Platt, F. Canonaco, P. Zotter, R. Wolf, S. M. Pieber, E. A. Bruns, M. Crippa, G. Ciarelli, A. Piazzalunga, M. Schwikowski, G. Abbaszade, J. Schnelle-Kreis, R. Zimmermann, Z. S. An, S. Szidat, U. Baltensperger, I. El Haddad and A. S. H. Prevot, Nature, 2014, 514, 218-222.

26 Z. Y. Meng, X. M. Jiang, P. Yan, W. L. Lin, H. D. Zhang and Y. Wang, Atmos. Environ., 2007, 41, 6901-6908.

27 Y. L. Feng, Y. J. Chen, H. Guo, G. R. Zhi, S. C. Xiong, J. Li, G. Y. Sheng and J. M. Fu, Atmos. Res., 2009, 92, 434-442.

28 Y. M. Huang, Y. Liu, L. Y. Zhang, C. Peng and F. M. Yang, Atmosphere, 2018, 9, 37.

29 L. H. Zhu, J. Tao, R. J. Zhang, J. J. Cao, T. Zhang, Z. J. Lin and Z. C. Xu, Acta Sci. Circumstantiae, 2010, 30, 1942-1949.

30 R. Zhang, J. Jing, J. Tao, S.-C. Hsu, G. Wang, J. Cao, C. S. L. Lee, L. Zhu, Z. Chen, Y. Zhao and Z. Shen, Atmos. Chem. Phys., 2013, 13, 7053-7074.

31 P. H. Li, B. Han, J. Huo, B. Lu, X. Ding, L. Chen, S. F. Kong, Z. P. Bai and B. Wang, Aerosol Air Qual. Res., 2012, 12, 283294.

32 S. Kong, B. Han, Z. Bai, L. Chen, J. Shi and Z. Xu, Sci. Total Environ., 2010, 408, 4681-4694.

33 W. F. Li, Z. P. Bai, A. X. Liu, J. Chen and L. Chen, Aerosol Air Qual. Res., 2009, 9, 105-119.
34 X. Li, Q. Zhang, Y. Zhang, L. Zhang, Y. X. Wang, Q. Q. Zhang, M. Li, Y. X. Zheng, G. N. Geng, T. J. Wallington, W. J. Han, W. Shen and K. B. He, Sci. Bull., 2017, 62, 957-964.

35 C. M. Pavuluri, K. Kawamura, T. Swaminathan and E. Tachibana, J. Geophys. Res.: Atmos., 2011, 116, D18307.

36 L. A. Martinelli, P. B. Camargo, L. B. L. S. Lara, R. L. Victoria and P. Artaxo, Atmos. Environ., 2002, 36, 2427-2432.

37 S. Bikkina, A. Andersson, K. Ram, M. M. Sarin, R. J. Sheesley, E. N. Kirillova, R. Rengarajan, A. K. Sudheer and O. Gustafsson, J. Geophys. Res.: Atmos., 2017, 122, 4903-4923.

38 R. Chesselet, M. Fontugne, P. Buatmenard, U. Ezat and C. E. Lambert, Geophys. Res. Lett., 1981, 8, 345-348.

39 J. D. Gleason and T. K. Kyser, Nature, 1984, 307, 254-257.

40 D. Widory, S. Roy, Y. Le Moullec, G. Goupil, A. Cocherie and

C. Guerrot, Atmos. Environ., 2004, 38, 953-961.

41 C. X. Guo, C. Shao and M. T. Ju, Res. J. Environ. Sci., 2012, 25, 232-239.

42 L. M. Castro, C. A. Pio, R. M. Harrison and D. J. T. Smith, Atmos. Environ., 1999, 33, 2771-2781.

43 D. S. Ji, J. K. Zhang, J. He, X. J. Wang, B. Pang, Z. R. Liu, L. L. Wang and Y. S. Wang, Atmos. Environ., 2016, 125, 293-306.

44 E. A. Stone, J. J. Schauer, B. B. Pradhan, P. M. Dangol, G. Habib, C. Venkataraman and V. Ramanathan, J. Geophys. Res., 2010, 115, D06301.

45 Y. J. Chen, G. R. Zhi, Y. L. Feng, J. M. Fu, J. L. Feng, G. Y. Sheng and B. R. T. Simoneit, Geophys. Res. Lett., 2006, 33, 382.

46 S. K. Saarikoski, M. K. Sillanpaa, K. M. Saarnio, R. E. Hillamo, A. S. Pennanen and R. O. Salonen, Water, Air, Soil Pollut., 2008, 191, 265-277.

47 Y. X. Zhang, M. Shao, Y. H. Zhang, L. M. Zeng, L. Y. He, B. Zhu, Y. J. Wei and X. L. Zhu, J. Environ. Sci., 2007, 19, 167-175.

48 J. J. Schauer, M. J. Kleeman, G. R. Cass and B. R. T. Simoneit, Environ. Sci. Technol., 2002, 36, 1169-1180.

49 J. J. Schauer, M. J. Kleeman, G. R. Cass and B. R. T. Simoneit, Environ. Sci. Technol., 1999, 33, 1578-1587.

50 J. J. Schauer, M. J. Kleeman, G. R. Cass and B. R. T. Simoneit, Environ. Sci. Technol., 2001, 35, 1716-1728.

51 L. Y. He, M. Hu, X. F. Huang, B. D. Yu, Y. H. Zhang and D. Q. Liu, Atmos. Environ., 2004, 38, 6557-6564.

52 J. J. Cao, S. C. Lee, K. F. Ho, X. Y. Zhang, S. C. Zou, K. Fung, J. C. Chow and J. G. Watson, Atmos. Environ., 2003, 37, 14511460.

53 H. A. Gray, G. R. Cass, J. J. Huntzicker, E. K. Heyerdahl and J. A. Rau, Environ. Sci. Technol., 1986, 20, 580-589.

54 S. G. Aggarwal and K. Kawamura, Atmos. Environ., 2009, 43, 2532-2540.

55 G. Kiss, B. Varga, I. Galambos and I. Ganszky, J. Geophys. Res.: Atmos., 2002, 107, D218339.

56 H. Yang, J. Z. Yu, S. S. H. Ho, J. H. Xu, W. S. Wu, C. H. Wan, X. D. Wang, X. R. Wang and L. S. Wang, Atmos. Environ., 2005, 39, 3735-3749.

57 Z. Zong, X. P. Wang, C. G. Tian, Y. J. Chen, G. X. Han, J. Li and G. Zhang, Atmos. Environ., 2016, 144, 124-132. 
58 B. R. T. Simoneit, M. Kobayashi, M. Mochida, K. Kawamura, M. Lee, H. J. Lim, B. J. Turpin and Y. Komazaki, J. Geophys. Res.: Atmos., 2004, 109, D19S10.

59 P. Fu, K. Kawamura, K. Usukura and K. Miura, Mar. Chem., 2013, 148, 22-32.

60 R. B. Gagosian, E. T. Peltzer and J. T. Merrill, Nature, 1987, 325, 800-804.

61 G. H. Wang, R. Y. Zhang, M. E. Gomez, L. X. Yang, M. L. Zamora, M. Hu, Y. Lin, J. F. Peng, S. Guo, J. J. Meng, J. J. Li, C. L. Cheng, T. F. Hu, Y. Q. Ren, Y. S. Wang, J. Gao,
J. J. Cao, Z. S. An, W. J. Zhou, G. H. Li, J. Y. Wang, P. F. Tian, W. Marrero-Ortiz, J. Secrest, Z. F. Du, J. Zheng, D. J. Shang, L. M. Zeng, M. Shao, W. G. Wang, Y. Huang, Y. Wang, Y. J. Zhu, Y. X. Li, J. X. Hu, B. Pan, L. Cai, Y. T. Cheng, Y. M. Ji, F. Zhang, D. Rosenfeld, P. S. Liss, R. A. Duce, C. E. Kolb and M. J. Molina, Proc. Natl. Acad. Sci. U. S. A., 2016, 113, 13630-13635.

62 A. Tilgner and H. Herrmann, Atmos. Environ., 2010, 44, 54155422. 